\title{
Katarina Trček
}

\section{Orgle in orgelska glasba v slovenski kulturni zgodovini do nastopa cecilijanstva}

Doktorska disertacija z naslovom Orgle in orgelska glasba v slovenski kulturni zgodovini do nastopa cecilijanstva raziskuje zgodovino postavljanja orgelskih glasbil na Slovenskem od začetkov v prvi polovici 15. stoletja do druge polovice 19. stoletja, ko so postale orgle obvezno glasbilo domala vsake župnijske cerkve. Kot zgornja časovna meja razprave je vzeto leto 1877, ko je bilo ustanovljeno Slovensko cecilijansko društvo, ki je prevzelo načrtnejšo skrb za glasbo v cerkvah. Namen disertacije je prikazati, kako so se širila orgelska glasbila v slovenski zgodovini, in ta razvoj ovrednotiti s stališča slovenske glasbene in kulturne zgodovine.

Disertacija ima tri osnovne vsebinske sklope: v prvem so zbrani podatki o vseh orgelskih glasbilih na Slovenskem do leta 1877; v drugem so raziskane in opisane glavne tendence v razvoju postavljanja orgel na Slovenskem; v tretjem je na osnovi ohranjenih muzikalij nakazano, kaj se je na orgelska glasbila v posameznih obdobjih igralo. Ne glede na nekdanje državne, pokrajinske in cerkvene meje se razprava omejuje na ozemlje današnje države Slovenije, ki ga pojmuje kot enovit kulturni prostor z lastno zgodovino.

Za uresničitev ciljev, je bilo potrebno zbrati podatke o vseh orglah, ki so bile kdajkoli postavljene na slovenskem do leta 1877. Tako je bilo na osnovi obsežne že obstoječe literature, terenskih ogledov in deloma tudi na osnovi študija primarnih virov mogoče identificirati natančno 772 orgel, od katerih jih je danes ohranjeno še 305. Podatki o vseh 772 glasbilih so zbrani v prvem poglavju, kjer so za vsako glasbilo navedeni osnovni podatki: čas izdelave, orglarski mojster, velikost, dispozicija in pri ohranjenih glasbilih, tudi njihovo današnje stanje. V izogib morebitnim dvoumnim zamenjavam je bilo potrebno vsako glasbilo identificirati; glasbila so identificirana z lokacijo in zaporedno številko. Lokacija je določena s prvim krajem postavitve glasbila in patrocinijem, številka ob lokaciji pa označuje zaporedje glasbila: »Ljubljana/sv. Nikolaj 2« pomeni časovno druge orgle ljubljanske cerkve sv. Nikolaja.

772 orgel, kolikor jih je bilo mogoče identificirati, gotovo ni vse, kar je do druge polovice 19. stoletja obstajalo na Slovenskem. Vendar je to število dovolj veliko, da dopušča zanesljive sklepe o slovenski orgelski zgodovini, do katerih privedejo odgovori na vprašanja o dinamiki postavljanja orgel, o rasti lokacij z orglami, o izdelovalcih glasbil, o skupnih organoloških značilnostih in o vlogi orgel v bogoslužju.

Odgovore obravnava drugi del disertacije in z njimi podaja celovit pogled na zgodovino postavljanja orgel na Slovenskem. Sprva je prikazana rast postavljanja orgelskih 
glasbil; medtem ko se je število novih orgel v 16. in 17. stoletju le postopoma večalo, je sredi 18. stoletja močno naraslo. Na prehodu iz 18. v 19. stoletje je upadlo, zato pa se je v tretjem desetletju 19. stoletja močno dvignilo in doseglo vrhunec sredi 19. stoletja. Nadalje je prikazana rast lokacij z orglami, ki jih je bilo iz desetletja v desetletje več. Krivulja rasti se zlasti strmo vzpenja začenši s tretjim desetletjem 19. stoletja in leta 1877 doseže 488 cerkva. Sledi vprašanje o izdelovalcih slovenskih orgel. Z ozirom na politično pripadnost slovenskega prostora je razumljivo, da so bili na Obali in v njenem zaledju sprva dejavni predvsem beneški orglarji, na Kranjskem in Štajerskem pa mojstri iz raznih avstrijskih dežel. Prvi na Slovenskem delujoči orglar je deloval v drugi polovici 17. stoletja na Kranjskem. Od tega časa dalje je število domačih orglarjev raslo in v prvi polovici 19. stoletja so potrebe po novih glasbilih skoraj v celoti pokrivali domači mojstri.

Zadnji del drugega poglavja se posveča vprašanju zvočne arhitekture obravnavanih glasbil, kot je razvidna iz ohranjenih dispozicij. Izkazalo se je, da je meja med starejšimi in mlajšimi glasbili prehod 18. v 19. stoletje. Znotraj vsakega od teh dveh obdobij so ohranjene dispozicije razvrščene v vrsto tipov, z ozirom na to, kakšno je razmerje med osnovnimi skupinami njihovih registrov (principalni, pokriti, flavtni, godalni, jezičniški registri). Iz razprave je razvidno, kateri tipi orgel so obstajali na Slovenskem in kateri med njimi so bili najbolj značilni. Splošna težnja razvoja je bila ta, da so bila glasbila vse večja in da se je v 19. stoletju močno povečal delež barvitih flavtnih in godalnih registrov.

Zadnji del disertacije skuša odgovoriti na vprašanje, kaj se je na slovenska orgelska glasbila v posameznih obdobjih igralo. Čeprav je bilo orgel zelo veliko, je glasbe, ki se je nanje igrala, razmeroma malo, kar velja zlasti za starejša obdobja. Nedvomno so orgle v vseh obdobjih zgodovine spremljale takšno ali drugačno petje pri bogoslužju, organisti so poleg spremljanja petja izvajali tudi orgelske kompozicije in improvizirali ustrezne preludije, interludije in postludije. Ta praksa je za 19. stoletje potrjena v sočasnih virih. Ducat pomembnejših slovenskih cerkva ima ohranjene muzikalije (različne bogoslužne vokalne skladbe), ki v zasedbi predpostavljajo tudi orgle, bodisi v vlogi bassa continua, ali obligatnega glasbila. Izrecno orgelskih skladb pa se je do leta 1877 ohranilo zelo malo.

S tem, ko disertacija nazorno kaže, kako so se do leta 1877 orgle povsem zasidrale v slovenski kulturni prostor in kako so bile kar najširše plasti prebivalstva v stiku z orglami, potrjuje hipotezo, da so orgle in orgelska glasba bistveni in nepogrešljivi del slovenske glasbene in kulturne zgodovine.

Obranjeno 7. oktobra 2015 na Filozofski fakulteti Univerze v Ljubljani. 